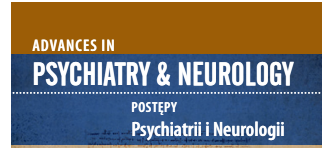

Correspondence to/

Adres do korespondencji:

Wojciech Oronowicz-Jaśkowiak

III Klinika Psychiatryczna

Instytut Psychiatrii i Neurologii

ul. Sobieskiego 9

00-957 Warszawa, Polska

e-mail: wojciechoronowicz@gmail.com

Submitted/Otrzymano: 27.02.2020

Accepted/Przyjęto do druku: 25.04.2020

\section{BINARY CLASSIFICATION \\ OF PORNOGRAPHIC AND \\ NON-PORNOGRAPHIC MATERIALS \\ USING THE SAI O.4 MODEL \\ AND THE MODIFIED SEXACT DATABASE}

\author{
KLASYFIKACJA BINARNA \\ MATERIAŁÓW PORNOGRAFICZNYCH \\ I NIEPORNOGRAFICZNYCH \\ ZA POMOCA MODELU SAI 0.4 \\ Z WYKORZYSTANIEM ZMODYFIKOWANEJ \\ BAZY SEXACT
}

\author{
Wojciech Oronowicz-Jaśkowiak', Edyta Bzikowska², \\ Klaudia Jabłońska ${ }^{3}$, Anita Kłok ${ }^{3}$
}

13rd Department of Psychiatry, Institute of Psychiatry and Neurology, Warsaw, Poland
${ }^{2}$ Faculty of Educational Sciences, University of Lodz, Poland

${ }^{3}$ Faculty of Social Sciences, Catholic University of Lublin, Poland

'III Klinika Psychiatryczna, Instytut Psychiatrii i Neurologii w Warszawie, Polska

${ }^{2}$ Wydział Nauk o Wychowaniu, Uniwersytet Łódzki, Polska

${ }^{3}$ Wydział Nauk Społecznych, Katolicki Uniwersytet Lubelski Jana Pawła II, Lublin, Polska

\begin{abstract}
Purpose: Neural networks may be used to solve problems in the field of psychology and sexology. In particular, it seems that neural networks may be important to limit the unintentional contact of minors with pornographic material. The aim of the study was to create the neural networks model for the classification of pornographic (also fetishist) materials from non-pornographic materials.

Methods: In order to create a new model, the sAI 0.3 model was used as the basic model. The fast.ai library version 1.0.55 was used. A modified version of ResNet152 was adopted as the neural network architecture. The sexACT database was modified to include new training material - 1630 non-pornographic photos of women. A total of 1304 photos ( $80 \%$ of the set) were used to train the network and the remaining 326 photos ( $20 \%$ of the set) were used for its later validation.

Results: As a result of the research, the sAI 0.4 model was created, enabling binary classification of pornographic and non-pornographic materials with $96 \%$ accuracy. The model tends to make more the first type of error than the second type of errors. The model has a high precision (0.94) and high sensitivity (0.88). The final validation loss was 0.1314 .

Conclusions: The potential benefits of using the discussed model from a clinical perspective were discussed. The application of the discussed model could prevent the negative effects of contact of minors with pornographic material, which could consequently limit the prevalence of risky sexual behavior or negative psychosocial effects.
\end{abstract}

Key words: neural networks, clinical sexology, pornographic materials.

\title{
Streszczenie
}

Cel: Sieci neuronowe mogą być wykorzystywane do rozwiązywania problemów mających znaczenie w psychologii i seksuologii. W szczególności wydaje się istotne wprowadzenie skutecznych mechanizmów mogących ograniczyć nieintencjonalny kontakt małoletnich z materiałami pornograficznymi. Celem badań było stworzenie modelu klasyfikacji zdjęć, który różnicowałby materiały pornograficzne (również o charakterze fetyszystycznym) od materiałów niepornograficznych (przedstawiających osoby bez ukazywania nagości i aktywności seksualnej). 
Binary classification of pornographic and non-pornographic materials using the sAl 0.4 model and the modified sexACT database

Klasyfikacja binarna materiałów pornograficznych i niepornograficznych za pomoca modelu sAl 0.4 z wykorzystaniem zmodyfikowanej bazy sexACT

Metody: W celu stworzenia nowego modelu zastosowano bazowo model sAI 0.3. Wykorzystano bibliotekę fast.ai w wersji 1.0.55. $\mathrm{Za}$ architekturę sieci neuronowej przyjęto zmodyfikowaną wersję ResNet152. Zmodyfikowano bazę sexACT, dodając do niej nowy materiał treningowy obejmujący 1630 zdjęć kobiet o charakterze niepornograficznym. Spośród nich 1304 zdjęcia (80\% zbioru) zostały użyte do wytrenowania sieci, a pozostałe 326 zdjęć ( $20 \%$ zbioru) do jej późniejszej walidacji.

Wyniki: W wyniku badań stworzono model umożliwiający klasyfikację binarną zdjęć o charakterze pornograficznym i niepornograficznym z 96\% dokładnością. Model charakteryzuje się tendencją do częstszego popełniania błędów pierwszego rodzaju niż błędów drugiego rodzaju. Model cechuje się wysoką precyzją $(0,94)$ oraz wysoką czułością $(0,88)$. Końcowa strata walidacji wynosiła 0,1314 .

Wnioski: W pracy omówiono potencjalne zalety wykorzystania omawianego modelu z perspektywy klinicznej. Zastosowanie omawianego modelu mogłoby pozwolić w szczególności na zapobieżenie negatywnym skutkom kontaktu małoletnich $\mathrm{z}$ materiałami pornograficznymi i tym samym występowaniu ryzykownych zachowań seksualnych czy też negatywnych skutków psychospołecznych.

Słowa kluczowe: sieci neuronowe, seksuologia kliniczna, materiały pornograficzne.

\section{INTRODUCTION}

It is assumed that early contact with pornographic materials may have negative consequences, both mentally and socially. One of the causes of increased vulnerability to the negative effects of viewing pornographic materials by minors is that their uncritical acceptance of beliefs about sexual activity may later affect their sexual life in adulthood [1, 2]. Izdebski [3] demonstrated that contact with pornography aroused negative emotions in 33\% of the adolescents he studied. This is also confirmed by the results of later research [4], which showed that among adolescents who were in contact with pornographic materials, $45 \%$ of girls and $31 \%$ of boys consequently experienced anxiety. A possible explanation is that pornography presents minors with an experience exceeding their adaptability and mental capacity.

Among other threats, researchers also draw attention to high risks related to sexting, which involves sending to others pictures of different degrees of nudity. It is also assumed that frequent contact with pornographic material may be related to premature sexual initiation ${ }^{1}$ with often adverse consequences. Sexual initiation which is considered to be too early is often associated with higher likelihood of problems in adult sexual life [5]. In fact, people who experience early initiation often express feelings of having a lower level of satisfaction with life, and are exposed to a higher risk of depression with suicidal thoughts or even attempts [6].

${ }^{1} \mathrm{~A}$ limitation of these conclusions is that it is impossible to show the cause-effect relationship here. An alternative explanation is that adolescents with a higher level of sexual arousal are also more likely to view pornographic materials, but earlier initiation is not taking place in such cases due to reduced sensitivity through frequent contact with pornographic materials, but rather through higher levels of sexual arousal.

\section{WPROWADZENIE}

Zakłada się, że wczesny kontakt z materiałami pornograficznymi może powodować negatywne konsekwencje zarówno w sferze psychicznej, jak i społecznej. Jako przyczynę większego narażenia na negatywne skutki oglądania materiałów pornograficznych przez małoletnich wymienia się, że bezkrytyczne przyjmowanie przekonań dotyczących aktywności seksualnej może w późniejszym czasie rzutować na realną aktywność seksualną podejmowaną w ciągu życia [1,2]. Izdebski [3] wykazał, że w przypadku $33 \%$ badanej przez niego młodzieży kontakt z pornografią wzbudził negatywne emocje. Potwierdzają to także wyniki późniejszych badań [4] ukazujące, że spośród młodzieży, która uzyskiwała kontakt z materiałami pornograficznymi, u 45\% dziewcząt i 31\% chłopców spowodowało to $\mathrm{w}$ konsekwencji odczucie niepokoju. Wyjaśnieniem obserwowanych wyników jest założenie, że pornografia stawia małoletniego przed doświadczeniem przerastającym jego możliwości adaptacyjne i psychiczne.

Wśród innych zagrożeń zwraca się uwagę na zwiększone ryzyko sekstingu wiążącego się z wysyłaniem innym osobom zdjęć, na których prezentowany jest różny stopień nagości. Zakłada się też, że częsty kontakt z materiałami pornograficzny może wiązać się ze zbyt wczesnym podjęciem inicjacji seksualnej ${ }^{1}$ mającej często niekorzystne konsekwencje. Zbyt wczesna inicjacja seksualna związana jest bowiem z częstszym doświadczaniem problemów w życiu seksualnym w wieku dojrzałym [5], przy czym osoby, które we własnym odczuciu doświadczyły wczesnej inicjacji, mają niższy poziom zadowolenia z życia oraz wyższe ryzyko depresji, myśli i prób samobójczych [6].

\footnotetext{
${ }^{1}$ Ograniczeniem przytaczanych wniosków jest brak możliwości ukazania zależności przyczynowo-skutkowej. Alternatywnym wyjaśnieniem jest to, że adolescenci odczuwający wyższy poziom pobudzenia seksualnego również częściej oglądają materiały pornograficzne, ale do wcześniejszej inicjacji nie dochodzi z powodu zmniejszenia wrażliwości poprzez częsty kontakt z materiałami pornograficznymi, tylko przez wyższy poziom pobudzenia seksualnego.
} 
On the Internet, pornographic materials are also found on sites which are not necessarily directly related to the pornographic industry, which increases the risk of unintended viewing of pornographic content, especially by minors. The introduction of mechanisms to avoid unwanted contact with pornographic materials is significant from a clinical point of view ${ }^{2}$, as this could allow for the development of strategies that reduce contact with pornography (including fetishistic pornography) among minors.

Artificial neural networks (otherwise known as deep neural networks) are mathematical structures; in the analysis of raster images they are used to recognize the types of patterns presented, which later allows for their classification [7]. If commonly used in commercial applications, neural networks are also successfully used to solve problems of a scientific nature. A comprehensive review of the existing models used in the analysis of pornographic materials and the use of neural networks in clinical and forensic sexology has been presented in an article by Oronowicz-Jaśkowiak [8].

Although neural networks are not currently widely used in sexological research, attempts are being made to create clinically useful models. Moustafa has created a model which enables the recognition of pictures and films that may present pornography involving minors with $94 \%$ effectiveness [9]. Another model designed to detect pornography involving minors in films - characterized by as much as a $98 \%$ accuracy of classification - was created by Perez et al. [10]. Also, Jin et al. [11] have created a model which makes it is possible to classify pornographic and non-pornographic images with $97 \%$ accuracy. Research on the use of neural networks in sexology has so far focused on the differentiation between pornographic and non-pornographic images; however, some studies have also highlighted another area of their application. As an example, we can mention the studies by Wang and Kosiński [12], who are the authors of the model which determines the sexual orientation of a person represented in a photo with $91 \%$ probability.

Pilot studies have shown that trained neural networks can differentiate between the types of pornographic material, whereas not every category of pornographic material must include nudity [13]. The effect of such research was the development of the first model of a neural network - sAI 0.1 - that can differentiate between the various categories of pornographic materials. The categories that were used to train the neural network included: sexual activity, BDSM,

${ }^{2}$ IT solutions used for automatic filtering of pornographic content are already in use (for example the Google SafeSearch filter). Their limitation, however, is that they don't filters for pornographic materials that do not necessarily display nudity but contain fetishistic elements
$\mathrm{W}$ internecie można natrafić na materiały pornograficzne na stronach niezwiązanych bezpośrednio z przemysłem pornograficznym, co zwiększa ryzyko nieplanowanego oglądania tego typu treści, szczególnie przez osoby małoletnie. Wprowadzenie mechanizmów pozwalających uniknąć niepożądanego kontaktu z materiałami pornograficznymi jest istotne $\mathrm{z}$ klinicznego punktu widzenia $^{2}$, ponieważ mogłoby to pozwolić na wprowadzenie rozwiązań ograniczających kontakt z pornografią (w tym fetyszystyczną) wśród małoletnich.

Sztuczne sieci neuronowe (inaczej głębokie sieci neuronowe) to struktury matematyczne, które $\mathrm{w}$ analizie obrazów rastrowych wykorzystuje się do rozpoznawania zadanych typów wzorców przedstawionych na zdjęciach, co w późniejszym czasie pozwala na dokonanie ich klasyfikacji [7]. Sieci neuronowe, o ile są powszechnie wykorzystywane w zastosowaniach komercyjnych, są również z powodzeniem stosowane do rozwiązywania problemów o charakterze naukowym. Wyczerpujący przegląd dotychczasowych modeli używanych $\mathrm{w}$ analizie materiałów pornograficznych oraz zastosowania sieci neuronowych w seksuologii klinicznej i seksuologii sądowej został zaprezentowany w artykule Oronowicza-Jaśkowiaka [8].

Choć sieci neuronowe nie są obecnie powszechnie wykorzystywane $\mathrm{w}$ badaniach seksuologicznych, podejmuje się próby stworzenia modeli użytecznych pod względem klinicznym. Moustafa stworzył model, który z 94\% skutecznością pozwala na rozpoznawanie zdjęć i filmów mogących przedstawiać pornografię z udziałem małoletnich [9]. Kolejny z modeli, mający służyć wykrywaniu pornografii $\mathrm{z}$ udziałem małoletnich na filmach - charakteryzujący się aż 98\% dokładnością klasyfikacji - został stworzony przez Pereza i wsp. [10]. Inny model zaprezentowali Jin i wsp. [11] - dzięki niemu możliwe jest klasyfikowanie zdjęć pornograficznych i niepornograficznych z 97\% dokładnością. Jak przedstawiono, badania nad zastosowaniem sieci neuronowych $\mathrm{w}$ seksuologii koncentrowały się zatem na różnicowaniu między zdjęciami pornograficznymi a niepornograficznymi, jednak publikowane były też badania zwracające uwagę na inny obszar zastosowań. Jako przykład można wymienić badania Wanga i Kosińskiego [12], którzy są autorami modelu z 91\% prawdopodobieństwem określającego, jakiej orientacji seksualnej jest osoba będąca na zdjęciu.

Badania pilotażowe wykazały, że wytrenowane sieci neuronowe pozwalają na rozróżnienie rodzajów materiałów pornograficznych, przy czym nie każda z kategorii materiałów pornograficznych musi obejmować nagość [13]. Efektem prowadzonych badań było udostępnienie pierwszego modelu sieci neuronowej - sAI 0.1 - pozwalającego na różnicowanie między kategoriami materiałów pornogra-

${ }^{2}$ Należy dodać, że rozwiązania informatyczne pozwalające na automatyczne ograniczenie treści pornograficznych już są stosowane (przykładowo - filtr Google SafeSearch). Ograniczeniem jest jednak brak uwzględnienia materiałów pornograficznych, na których niekoniecznie eksponowana jest nagość, ale widoczne są elementy fetyszystyczne. 
group sexual activity, animated sexual activity, fetishism - knee socks, fetishism - paraphilic infantilism, fetishism - feet. Based on the pilot model, the author has also shown the possibility of using neural networks in forensic-sexual expertise, which could support the work of forensic experts in sexology. These studies confirmed the validity of the use of neural networks in relation to implementations associated with the differentiation of pornographic materials.

Recently, an improved model allowing for the detection and classification of pornographic materials, including materials related to fetish categories (sAI 0.3), has been developed [14]. Thanks to changes in the network architecture and the introduction of a more restrictive method of including training data, the effectiveness of the differentiation between nine classes of pornographic materials was achieved at $92 \%$. The limitation of this model is the lack of inclusion of non-pornographic images in the training material, even though the introduction of this type of category would allow for binary differentiation between pornographic and non-pornographic material. Adding a tenth class to the introduced model would additionally allow for the reliability of the classification to be verified. $^{3}$

The aim of this study was to create a model for differentiating between pornographic and non-pornographic materials ${ }^{4}$ using the sAI 0.3 basic classification model for pornographic materials in order to determine the reliability of the classification and to prepare a filterable solution for pornographic content.

\section{METHODS}

The starting point for creating the current classifier was model sAI 0.3 [14]. This model was previously trained on a collection of 4,500 images, allowing for the differentiation between nine classes of pornographic material with almost $92 \%$ accuracy. The fast.ai library ${ }^{5}$ in version 1.0.55 was used [15]. Default data augmentation was

\footnotetext{
${ }^{3}$ Understood as the ability to differentiate between any pornographic and non-pornographic images.

${ }^{4}$ For the purposes of this publication, the definition of pornographic materials has been adopted after the definition referring to the criteria for including pornographic materials in the sexACT database [13]. Pornographic materials are understood as those that have been marked by the producers as materials causing sexual arousal in viewers or a specific group of viewers. However, this is not the only definition of pornographic materials [16].

${ }^{5}$ Neural networks are trained in specific libraries that define their possible future use. The most popular libraries providing for working with neural networks include Keras, TensorFlow and PyTorch. The decision to use fast.ai [1] library was made due to the fact that it provides for an easier integration with extensions that allow for practical use of neural networks.
}

ficznych. Do kategorii, które zostały użyte do wytrenowania sieci neuronowej, zaliczono: aktywność seksualną, BDSM, aktywność seksualną grupową, aktywność seksualną animowaną, fetyszyzm - podkolanówki, fetyszyzm - infantylizm parafiliczny, fetyszyzm - stopy. Autor, bazując na modelu pilotażowym, ukazał ponadto możliwość zastosowania sieci neuronowych w opiniowaniu sądowo-seksuologicznym, co mogłoby wspomóc pracę biegłych sądowych z zakresu seksuologii. Badania te potwierdzily zasadność zastosowania sieci neuronowych $w$ odniesieniu do wdrożeń związanych $\mathrm{z}$ różnicowaniem materiałów pornograficznych.

$\mathrm{W}$ ostatnim czasie zaprezentowano ulepszony model pozwalający na wykrywanie i klasyfikację materiałów pornograficznych, w tym materiałów odnoszących się do kategorii fetyszystycznych (sAI 0.3) [14]. Dzięki zmianom w architekturze sieci i wprowadzeniu bardziej restrykcyjnej metody włączania danych treningowych uzyskano skuteczność różnicowania między dziewięcioma klasami materiałów pornograficznych wynoszącą 92\%. Ograniczeniem prezentowanego modelu jest brak uwzględnienia $\mathrm{w}$ materiale treningowym zdjęć innych niż pornograficzne. Dzięki wprowadzeniu kategorii tego typu możliwe byłoby różnicowanie binarne między materiałami pornograficznymi a niepornograficznymi. Dodanie dziesiątej klasy do wprowadzonego modelu pozwoliłoby dodatkowo na zweryfikowanie rzetelności klasyfikacji3.

Celem niniejszych badań było stworzenie modelu różnicującego materiały pornograficzne od niepornograficznych przy użyciu bazowego modelu klasyfikacji materiałów pornograficznych ${ }^{4}$ sAI 0.3 , tak aby określić rzetelność dokonywanej klasyfikacji, oraz w celu przygotowania rozwiązania możliwego do filtrowania treści o charakterze pornograficznym.

\section{METODY}

Punktem wyjścia do stworzenia bieżącego klasyfikatora był model sAI 0.3 [14]. Model sAI 0.3 został wcześniej wytrenowany na zbiorze liczącym 4500 zdjęć, umożliwiającym różnicowanie między dziewięcioma klasami materiałów pornograficznych z blisko 92\% dokładnością. Wykorzystano bibliotekę fast.ai ${ }^{5} \mathrm{w}$ wersji 1.0.55 [15].

\footnotetext{
${ }^{3}$ Rozumianej jako zdolności do różnicowania między zdjęciami o charakterze pornograficznym a zdjęciami niepornograficznymi.

${ }^{4} \mathrm{Na}$ użytek niniejszej publikacji definicja materiałów pornograficznych została przyjęta za definicją odnoszącą się do kryteriów włączenia materiałów pornograficznych do bazy sexACT [13]. Materiały pornograficzne są rozumiane jako te, które zostały oznaczone przez producentów jako materiały wywołujące pobudzenie seksualne u odbiorców lub specyficznej grupy odbiorców. Nie jest to jednak jedyna definicja materiałów pornograficznych [16].

${ }^{5}$ Sieci neuronowe są trenowane w określonych bibliotekach określających później możliwości ich zastosowania. Do najpopularniejszych bibliotek umożliwiających pracę z sieciami neuronowymi należą Keras, TensorFlow oraz PyTorch. Zadecydowano o wykorzystaniu biblioteki fast.ai [1], ponieważ umożliwia ona łatwiejszą integrację z rozszerzeniami pozwalającymi na praktyczne wykorzystanie sieci neuronowej.
} 
Table 1. Quality criteria for the research material

Tabela 1. Kryteria jakości materiału badawczego

\begin{tabular}{|l|}
\hline Inclusive criteria/Kryteria włączające \\
\hline 1. Image resolution of at least $800 \times 600$ px./Rozdzielczość zdjęcia \\
wynosząca co najmniej $800 \times 600$ px. \\
2. Images in .jpeg or .jpg format./Zdjęcia w formacie .jpeg lub .jpg.
\end{tabular}

Exclusive criteria/Kryteria wyłączające

1. Unclear or blurred image that makes it impossible to identify the types of objects in the images./Niewyraźny obraz uniemożliwiający identyfikację typów obiektów przedstawionych na zdjęciach.

2. Image resolution less than $800 \times 600$ px./Rozdzielczość zdjęcia mniejsza niż $800 \times 600$ px.

3. Photos in other formats, especially vector graphics./Zdjęcia w innych formatach, w szczególności grafiki wektorowe. used $^{6}$. The calculations were performed on a computer with the following hardware configuration: Linux Ubuntu 18.04.3 LTS, 64 GB DDR4 RAM, Intel Core i5-9400F 2.90 GHz, NVIDIA GeForce RTX 2070 8GB DDR6. The material used to train the network and then validate it, totaled 1630 images; 1304 images (80\% of the collection) were used to train the network and the remaining 326 images ( $20 \%$ of the collection) were used for subsequent validation. The process of model training consisted of three stages - preparation of the training and validation material (photographs of adult women of non-pornographic nature), introduction of changes to the network architecture and conducting training and adjustment of hyperparameters.

\section{Stage 1: Preparation of the training and validation material}

In order to train the sAI 0.3 model to allow for the classification of the types of pornographic materials, materials containing images of adult women of a non-pornographic nature were downloaded from Internet sources and described. Due to the characteristics of the class to which the model was ascribed, images of adult women were downloaded, while at the same time images showing nude women or men were excluded. In addition, the initial selection of images was based on their quality and type of graphics (see Table 1). Each image was described in a database containing basic and additional characteristics of the images used for training the network and its subsequent validation (see Table 2).

\section{Stage 2. Network architecture}

We used model corresponding to the ResNet $152^{7}$ architecture $[14,17]$. The baseline model of a convolutional

\footnotetext{
${ }^{6}$ This is a process that can be compared to artificial modification of photos (part of the set of photos from the training set was randomly processed - reversed, brightened) in such a way as to increase the amount of training material.

${ }^{7}$ ResNet152 is a model trained on a large amount of training material, whose use allows to significantly speed up the training of the network and consequently teach it to recognize new classes of objects (in this case pornographic material).
}

Zastosowano domyślną augmentację danych ${ }^{6}$. Obliczenia były prowadzone na komputerze o następującej konfiguracji sprzętowej: Linux Ubuntu 18.04.3 LTS, 64 GB DDR4 RAM, Intel Core i5-9400F $2.90 \mathrm{GHz}$, NVIDIA GeForce RTX 2070 8GB DDR6. Materiał użyty do wytrenowania sieci, a następnie do jej zwalidowania stanowiło łącznie 1630 zdjęć, z czego 1304 zdjęcia (80\% zbioru) zostały użyte do wytrenowania sieci, a pozostałych 326 zdjęć (20\% zbioru) do jej późniejszej walidacji. Proces trenowania modelu składał się z trzech etapów - przygotowania materiału treningowego i walidacyjnego (zdjęcia dorosłych kobiet o charakterze niepornograficznym), wprowadzenia zmian do architektury sieci oraz prowadzenia treningu i dostosowywania hiperparametrów.

\section{Ełap 1. Przygotowanie materiału treningowego i walidacyjnego}

W celu dotrenowania modelu sAI 0.3 , tak aby umożliwić klasyfikację typów materiałów pornograficznych, pobierano i opisywano materiały zawierające zdjęcia dorosłych kobiet o charakterze niepornograficznym z zasobów internetu. Z uwagi na charakterystykę klasy, do której dotrenowano model, pobierane były zdjęcia dorosłych kobiet, przy jednoczesnym wykluczeniu zdjęć przedstawiających nagość kobiet lub mężczyzn. Przy wstępnej selekcji zdjęć kierowano się ponadto ich jakością i typem grafiki (zob. tab. 1). Każde zdjęcie zostało opisane w bazie danych zawierającej podstawową i dodatkową charakterystykę zdjęć użytych do treningu sieci oraz jej późniejszej walidacji (zob. tab. 2).

\section{Ełap 2. Architektura sieci}

Bazując na wcześniejszych badaniach [14], użyto modelu sAI 0.3 odpowiadającego architekturze ResNet152 $2^{7}$ [17]. Model bazowy konwolucyjnej sieci neuro-

${ }^{6}$ Jest to proces, który można porównać do sztucznej modyfikacji zdjęć (część zbioru zdjęć ze zbioru treningowego była poddawana losowej obróbce - odwróceniu, rozjaśnieniu) w taki sposób, aby zwiększyć ilość materiału treningowego.

${ }^{7}$ Model ResNet152 to model wytrenowany na dużej ilości materiału treningowego, którego wykorzystanie pozwala na znaczne przyśpieszenie treningu sieci i w konsekwencji nauczenie jej rozpoznawania nowych klas obiektów (w tym wypadku materiałów pornograficznych). 
Binary classification of pornographic and non-pornographic materials using the sAl 0.4 model and the modified sexACT database

Klasyfikacja binarna materiałów pornograficznych i niepornograficznych za pomoca modelu sAl 0.4 z wykorzystaniem zmodyfikowanej bazy sexACT

Table 2. Characteristics of images the used to train the neural network

Tabela 2. Podstawowa charakterystyka zdjęć użytych do wytrenowania sieci neuronowej

\begin{tabular}{|c|c|c|c|c|c|}
\hline $\begin{array}{c}\text { Presented } \\
\text { persons aged } \\
18-30 / \\
\text { Występowanie } \\
\text { osób w wieku od } \\
18 \text { do } 30 \text { lat }\end{array}$ & $\begin{array}{c}\text { Presented } \\
\text { persons aged } \\
30-50 / \\
\text { Występowanie } \\
\text { osób w wieku od } \\
30 \text { do } 50 \text { lat }\end{array}$ & $\begin{array}{l}\text { Presented persons } \\
\text { aged over } 50 \text { years old/ } \\
\text { Występowanie osób } \\
\text { w wieku powyżej } 50 \text { lat }\end{array}$ & $\begin{array}{l}\text { Number of persons/ } \\
\text { Liczba osób }\end{array}$ & $\begin{array}{l}\text { Number of women/ } \\
\text { Liczba kobiet }\end{array}$ & $\begin{array}{l}\text { Number of men/ } \\
\text { Liczba mężczyzn }\end{array}$ \\
\hline $\begin{array}{c}\text { None/Brak } \\
\left(n^{\prime}=210 ; 15 \%\right) \\
\text { Yes/Tak } \\
\left(n^{\prime}=1421 ; 85 \%\right)\end{array}$ & $\begin{array}{c}\text { None } / \text { Brak } \\
(n=1488 ; 91 \%) \\
\text { Yes } / \text { Tak } \\
(n=143 ; 9 \%)\end{array}$ & $\begin{array}{c}\text { None } / \text { Brak } \\
(n=1577 ; 97 \%) \\
\text { Yes } / \text { Tak } \\
(n=54 ; 3 \%)\end{array}$ & $\begin{array}{l}\operatorname{Min}^{2}=1, \max ^{3}=10 \\
M^{4}=1.27, S^{5}=0.81\end{array}$ & $\begin{array}{l}\mathrm{Min}=1, \max =10 \\
M=1.17, S D=1.17\end{array}$ & $\begin{array}{c}M i n=0, \max =8 \\
M=0.11, S D=0.46\end{array}$ \\
\hline Nature/Natura & Sport/Sport & Home/Dom & Work/Praca & $\begin{array}{c}\text { Indoors/ } \\
\text { Pomieszczenie }\end{array}$ & Car/Samochód \\
\hline $\begin{array}{c}\text { None } / \text { Brak } \\
(n=1220 ; 75 \%) \\
\text { Yes/Tak } \\
(n=409 ; 25 \%)\end{array}$ & $\begin{array}{c}\text { None } / \text { Brak } \\
(n=1224 ; 75 \%) \\
\text { Yes } / \text { Tak } \\
(n=407 ; 25 \%)\end{array}$ & $\begin{array}{c}\text { None/Brak } \\
(n=571 ; 35 \%) \\
\text { Yes/Tak } \\
(n=60 ; 4 \%) \\
\text { No data/Brak danych } \\
(n=1000 ; 61 \%)^{6}\end{array}$ & $\begin{array}{c}\text { None } / \text { Brak } \\
(n=474 ; 29 \%), \\
\text { Yes/Tak } \\
(n=157 ; 10 \%), \\
\text { No data/Brak danych } \\
(n=1000 ; 61 \%)\end{array}$ & $\begin{array}{c}\text { None/Brak } \\
(n=529 ; 32 \%) \\
\text { Yes/Tak } \\
(n=102 ; 6 \%) \\
\text { No data/Brak danych } \\
(n=1000 ; 62 \%)\end{array}$ & $\begin{array}{c}\text { None/Brak } \\
(n=519 ; 32 \%), \\
\text { Yes/Tak } \\
(n=480 ; 29 \%), \\
\text { No data/Brak danych } \\
(n=1000 ; 39 \%)\end{array}$ \\
\hline
\end{tabular}

${ }^{7} N$ umber of persons/Liczba osób; ${ }^{2}$ Minimum number of persons in the image/Minimalna liczba osób na danym zdjęciu; ${ }^{3} \mathrm{Maximum}$ number of persons in the image/Maksymalna liczba osób na danym zdjęciu; 'Average number of persons in the image/Średnia liczba osób na danym zdjęciu; ${ }^{5}$ Standard deviation of the number of persons in the image/Odchylenie standardowe liczby osób na danym zdjęciu; "In some categories ("home", "work", "indoors", "car") the number of missing data is "1000", because these were not the categories described by all persons who developed the database. These were the mandatory categories for all persons developing the database: "presence of persons aged 18-30", "presence of persons aged 30-50", "presence of persons aged over 50", "total number of persons", "number of women", "number of men", "nature”, "sport”./W przypadku wybranych kategorii ("dom”, „praca”, „pomieszczenie”, "samochód") liczba brakujących danych wynosi "1000", ponieważ nie były to kategorie opisywane przez wszystkie osoby kompletujące bazę danych. Kategoriami obligatoryjnymi dla wszystkich osób konstruujacych bazę danych były następujące kategorie: "występowanie osób w wieku od 18 do 30 lat", "występowanie osób w wieku od 30 do 50 lat", "występowanie osób w wieku powyżej 50 lat", „liczba osób”, "liczba kobiet”, "liczba mężczyzn”, "natura”, „sport”.

Table 3. Basic characteristics of the neural network after hyperparameter tuning cycles Tabela 3. Podstawowa charakterystyka sieci neuronowej po cyklach dostrajania hiperparametrów

\begin{tabular}{|l|c|c|c|}
\hline Stages/Ełapy & Training loss/Strata trenowania & Validation loss/Strata walidacji & Accuracy/Dokładność \\
\hline Stage 1/Etap 1 & 0.3181 & 0.1890 & $92.78 \%$ \\
\hline Stage 2/Etap 2 & 0.2579 & 0.1466 & $94.67 \%$ \\
\hline Stage 3/Etap 3 & 0.2648 & 0.1329 & $95.98 \%$ \\
\hline Stage 4/Etap 4 & 0.2355 & 0.1316 & $95.48 \%{ }^{1}$ \\
\hline
\end{tabular}

${ }^{\prime}$ Due to visible signs of overtraining, further stages of network tuning were abandoned./Z uwagi na widoczne oznaki przetrenowania zaniechano dalszych etapów dostrajania sieci.

Table 4. Final values of network training after hyperparameter tuning Tabela 4. Końcowe wartości treningu sieci po dostrojeniu hiperparametrów

\begin{tabular}{|c|c|c|}
\hline Training loss/Strata trenowania & Validation loss/Strata walidacji & Accurracy/Dokładność \\
\hline 0.2355 & 0.1314 & $95.98 \%$ \\
\hline Precision/Precyzja & Sensitivity/Czułośćc & $\begin{array}{c}\text { Percentage of falsely positive results/ } \\
\text { Odsetek wyników fałszywie dodatnich (fall-ouf) }\end{array}$ \\
\hline 0.94 & 0.88 & 0.027 \\
\hline
\end{tabular}

Table 5. Classification matrix for the validation material - pornographic and non-pornographic images Tabela 5. Macierz klasyfikacji na materiale walidacyjnym - zdjęcia pornograficzne i zdjęcia niepornograficzne

\begin{tabular}{|c|c|c|c|}
\hline & & \multicolumn{2}{|c|}{ Real categories ${ }^{1}$ Kategorie w rzeczywistości ${ }^{1}$} \\
\hline \multirow{3}{*}{$\begin{array}{c}\text { Categories in network/ } \\
\text { Kategorie przewidziane } \\
\text { przez sieć }\end{array}$} & & Non-pornographic/Bez pornografii & Pornographic/Pornografia \\
\hline & $\begin{array}{l}\text { Non-pornographic/ } \\
\text { Bez pornografii }\end{array}$ & 281 & 16 \\
\hline & Pornographic/Pornografia & 39 & 583 \\
\hline
\end{tabular}

'The number of all categories does not add up to the value of the validation material, because the validation also used the material containing pornographic images from the sexACT 0.3 database (the total number of images used for validation was 919)./Liczba wszystkich kategorii nie sumuje się do wartości materiału walidacyjnego, ponieważ w walidacji wykorzystano również materiał zawierający zdjęcia pornograficzne z bazy sexACT 0.3 (łączna liczba zdjęć użytych do walidacji wynosiła 919). 


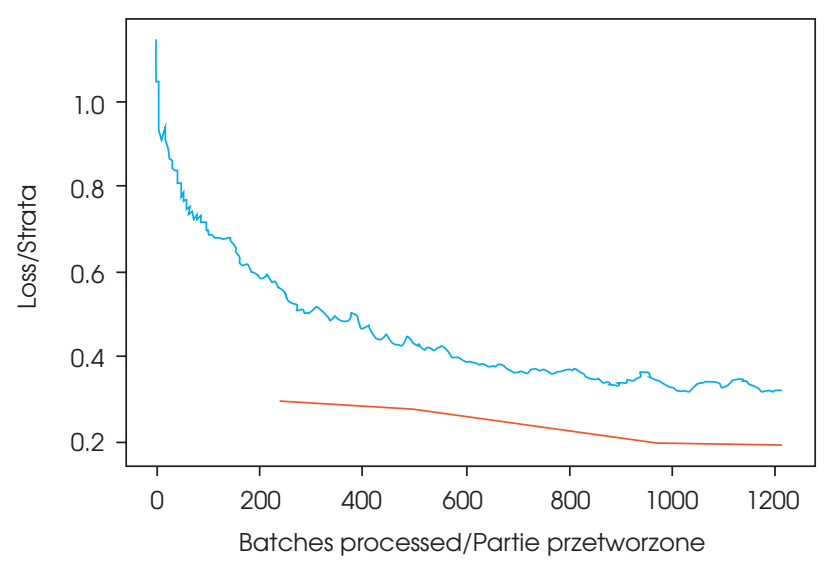

Figure 1. A graph showing the change in validation loss and training loss (the lower these values, in particular the loss of validation, the better the network in identifying objects) with subsequent training cycles

Rycina 1. Wykres przedstawiający zmianę straty walidacji i straty trenowania (im niższe są te wartości, w szczególności strata walidacji, tym sieć jest lepsza w rozpoznawaniu obiektów) z kolejnymi cyklami treningu

A

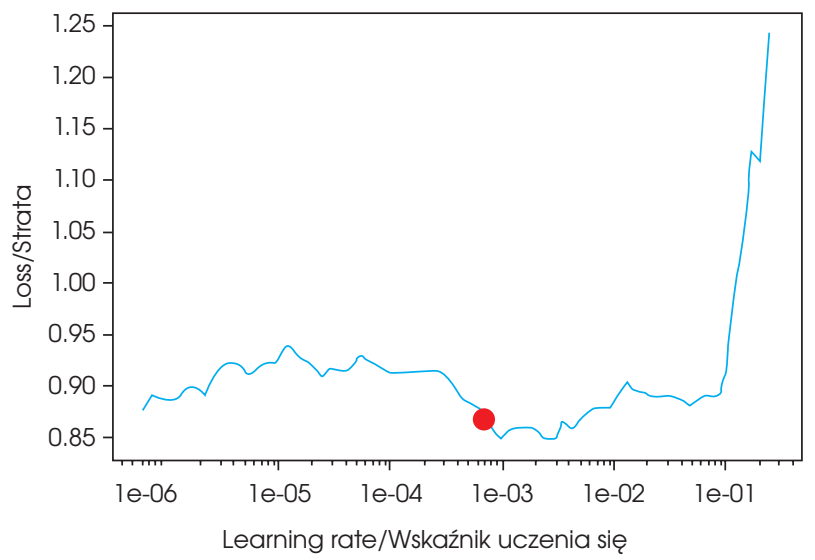

C

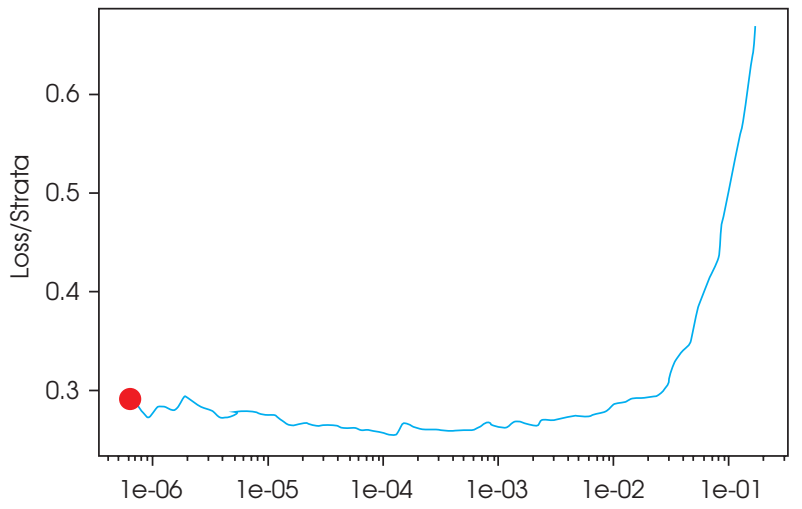

Learning rate/Wskaźnik uczenia się

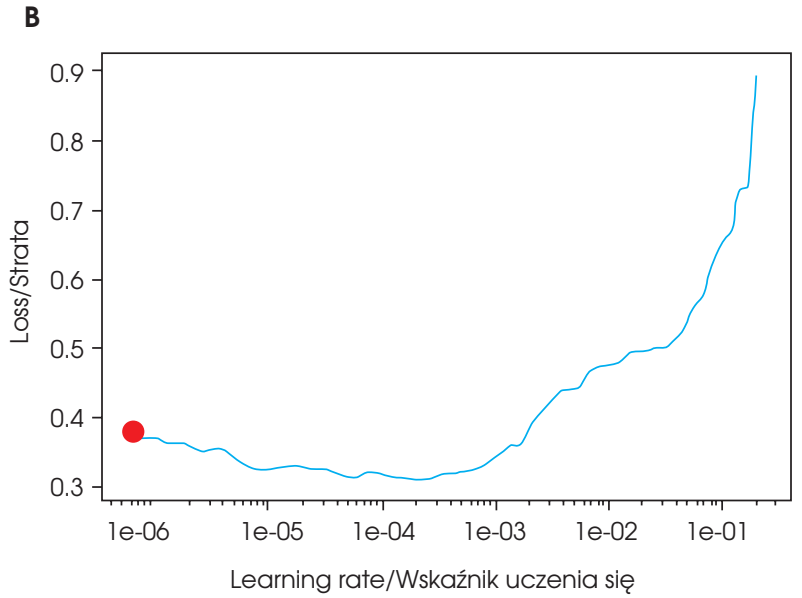

D

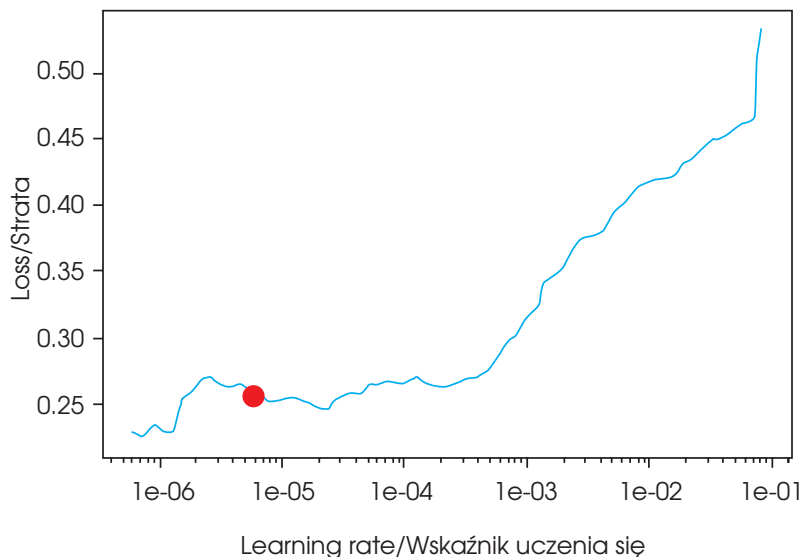

Figure 2. Graphs showing the optimal range of learning (indicated by a red dot) - this value is used to tune the network, to improve its parameters

Rycina 2. Wykresy przedstawiające optymalny zakres uczenia się (na rycinie wyznaczono, wskazując czerwonym punktem) - wartość ta jest wykorzystywana do dostrajania sieci, poprawy jej parametrów 
neural network $(\mathrm{CNN})^{8}$ consists of several hundred layers. Changes were introduced to the architecture, consisting in adding more convolutional layers (Conv2d, BatchNorm2d). The task of binary classification between two classes was assumed (pornographic and non-pornographic photos) $)^{9}$.

\section{Stage 3. Stage of network training and hyperparameter tuning}

After the first two cycles of network training (one cycle policy), calculations were made to determine the step function [18]. Figure 1 shows the change in validation loss and training loss with the subsequent training cycles. Figure 2 shows the optimal learning ranges for the network. The neural network was then trained on the basis of the indicated areas, in five training cycles. Table 3 shows the basic parameters of the neural network after each training phase. The final characteristics of the model are presented in Table 4. Table 5 presents errors in the classification of the materials that were made when classifying with the use of the presented model.

\section{DISCUSSION AND IMPLICATIONS FOR CLINICAL PRACTICE}

The process of constructing a neural network allowing for differentiation between the various categories of pornographic material consisted of several stages. Initially, a pilot model of the neural network was created, in order to distinguish between seven types of material [13]. Thanks to the introduction of two new categories and more restrictive inclusive criteria for the network training, a higher accuracy of classification was obtained [14]. It was for the first time in this study that a category referring to non-pornographic images was considered, i.e. images of adult women photographed in engaged in different activities and settings. As presented in the results, the new material of a non-pornographic nature varied in terms of the photographed women's age and settings.

The presented model allows for a high degree of differentiation between pornographic (including fetishist) and non-photographic images of women (see Table 5). The effectiveness of the binary classification in the current model is $96 \%$, which - compared to similar studies - can be considered a high value $[9,11]$. Notably, comparing the model created to the sAI 0.3 base model [14], it can be observed that it has a higher classification ac-

\footnotetext{
${ }^{8}$ Convolutional neural networks are used for recognition of patterns in given types of raster images.

${ }^{9}$ The sAI 0.3 model allows for differentiation between the following classes: "AB/DL", "BDSM", "acrotomophilia", "fetishism - feet", "fetishism - gravitophilia", "fetishism - high heels", "fetishism - knee socks", "fetishism - latex", "fetishism - tattoos". All the above categories were included in the category of "pornographic materials" used in the current research.
}

nowej ${ }^{8}$ składa się z kilkuset warstw. Wprowadzono zmiany $\mathrm{w}$ architekturze polegające na dodaniu kolejnych warstw konwolucyjnych (Conv2d, BatchNorm2d). Założono zadanie klasyfikacji binarnej między dwiema klasami (zdjęcia pornograficzne i zdjęcia niepornograficzne) $)^{9}$.

\section{Ełap 3. Ełap treningu sieci oraz dostrajanie hiperparametrów}

Po przeprowadzeniu dwóch pierwszych cykli treningu sieci (one cycle policy) przeprowadzono obliczenia związane z określeniem funkcji kroku [18]. Na rycinie 1 przedstawiono zmianę straty walidacji i straty trenowania wraz $\mathrm{z}$ kolejnymi cyklami treningu. Na rycinie 2 przedstawiono optymalne zakresy uczenia się dla sieci. W dalszej kolejności dotrenowano sieć neuronową, bazując na wskazanych obszarach i wykonując pięć cykli treningu. W tabeli 3 podano podstawowe parametry sieci neuronowej po kolejnych fazach treningowych. Końcowa charakterystyka modelu została przedstawiona $\mathrm{w}$ tabeli 4 . W tabeli 5 zestawiono błędy w klasyfikacji materiałów, które zostały popełnione przy klasyfikacji z użyciem prezentowanego modelu.

\section{DYSKUSJA WYNIKÓW I ZNACZENIE DLA PRAKTYKI KLINICZNEJ}

Etap konstruowania sieci neuronowej pozwalającej na różnicowanie między kategoriami materiałów pornograficznych składał się z kilku etapów. Na początku stworzono pilotażowy model sieci pozwalającej na dokonanie rozróżnienia między siedmioma typami materiałów pornograficznych [13]. Dzięki wprowadzeniu dwóch nowych kategorii materiałów i bardziej restrykcyjnych kryteriów włączenia materiałów do treningu sieci uzyskano wyższą dokładność klasyfikacji [14]. W niniejszym badaniu uwzględniono po raz pierwszy kategorię odnoszącą się do zdjęć niepornograficznych dorosłych kobiet podczas podejmowania różnych aktywności, $\mathrm{w}$ różnej scenerii. Jak przedstawiono $\mathrm{w}$ wynikach, nowy materiał o charakterze niepornograficznym był zróżnicowany pod względem wieku kobiet i otoczenia.

Zaprezentowany model pozwala na różnicowanie $\mathrm{z}$ wysoką skutecznością między materiałami pornograficznymi (w tym fetyszystycznymi) a zdjęciami kobiet o charakterze niepornograficznym (zob. tab. 5). Skuteczność klasyfikacji binarnej bieżącego modelu wynosi $96 \%$, co w porównaniu z podobnymi badaniami można uznać za wysoką wartość $[9,11]$. Porównując stworzony model do modelu bazowego sAI 0.3 [14], można zauważyć, że cechuje się on wyż-

${ }^{8}$ Konwolucyjne, inaczej splotowe, sieci neuronowe wykorzystuje się przy rozpoznawaniu wzorców w zadanych typach obrazów rastrowych.

${ }^{9}$ Model sAI 0.3 umożliwia różnicowanie między następującymi klasami: „AB/DL”, „BDSM”, „akrotomofilia”, „fetyszyzm - stopy”, „fetyszyzm - grawiditofilia”, „fetyszyzm - szpilki”, „fetyszyzm - podkolanówki”, „fetyszyzm - lateks”, „fetyszyzm - tatuaże”. Wszystkie powyższe kategorie zostały włączone do kategorii „materiałów pornograficznych” wykorzystanych w bieżących badaniach. 
curacy ( $92 \%$ vs. $96 \%$ ), yet the sAI 0.3 model allows for the classification of between nine and not two classes of pornographic material. However, the sAI 0.4 model supplements the previous studies with a class of non-pornographic material.

According to the classification matrix, the model has a tendency to make type I errors much more frequently than type II (see Table 4). It seems that the use of the model to filter out content that may be unsuitable for minors is the right trend ${ }^{10}$. The use of a low number of images of men is also a limitation of the model, which, on the one hand, is due to the nature of the pornographic content under investigation, but, on the other hand, it can make it difficult to classify when sexual intercourse is occurring undertaken. Another limitation is the failure to provide information on the reliability of the classification between pictures showing nudity or sexual activity of men and images of men which are of a non-pornographic nature.

One of the basic applications of the model is the possibility of including it in the mechanisms that filter for content that may be unsuitable for minors. This seems to be important from a health protection point of view for at least three reasons - providing the possibility of avoiding contact with pornographic material, preventing risky sexual behavior, and preventing negative psycho-social consequences for minors.

It is indicated that $42 \%$ of adolescents may have had contact with pornographic materials, although importantly, in $66 \%$ of cases the contact is unintentional [19]. Research shows that some children have unintentional contact with pornography, e.g. through unwanted e-mails [20]. Therefore, the introduction of a tool which would allow for the filtering of pornographic content could help avoid unintentional contact with these materials. It would also make it possible to curb any potentially harmful sexualization at an early stage [21], which may be particularly important in view of the results showing that early contact with pornography correlates with addiction to it in later years [22].

As suggested earlier, pornographic content influences the formation of an anomalous ${ }^{11}$ image of sexual relations [23]. It has been shown that viewing pornographic materials may result in premature ${ }^{12}$ sexual behaviour [24], which may, in turn, be associated with more frequent experience of sexual problems in adulthood, compared to people who initiate sexual activity at a later stage [6]. An early age of sexual initiation is also

${ }^{10}$ To avoid potentially negative effects of contact with pornographic materials, it is better to excessively trigger "false alarms" and filter image data than to make an error of oversight.

${ }^{11}$ Incorrect, because it can present a type of sexual activity that may in fact occur in the future incomparably less often, and which affects the misconceptions about sexuality.

${ }^{12}$ Understood as sexual contact that was judged by at least one party (usually girls) to be unwanted and premature. szą dokładnością klasyfikacji ( $92 \%$ vs 96\%), niemniej model sAI 0.3 umożliwia klasyfikację między dziewięcioma, a nie dwoma klasami materiałów pornograficznych. Stworzony model sAI 0.4 uzupełnia jednak badania prowadzone wcześniej o klasę materiałów niepornograficznych.

Jak wynika z macierzy klasyfikacji, model cechuje się tendencją do popełniania błędów I rodzaju, znacznie rzadziej popełniając błędy II rodzaju (zob. tab. 4). Wydaje się, że wykorzystanie go do filtrowania treści mogących być nieodpowiednimi dla małoletnich to właściwa tenden$\operatorname{cja}^{10}$. Do ograniczeń należy też niewielka liczba mężczyzn, co $\mathrm{z}$ jednej strony wynika $\mathrm{z}$ charakteru badanych treści pornograficznych, a z drugiej może utrudniać klasyfikację, w przypadku gdy podejmowany będzie stosunek seksualny. Ograniczeniem modelu jest również brak dostarczenia informacji o rzetelności klasyfikacji między zdjęciami przedstawiającyminagośćlubaktywnośćseksualną mężczyzn a zdjęciami mężczyzn o charakterze niepornograficznym.

Jedno z podstawowych zastosowan modelu to możliwość uwzględnienia go w mechanizmach filtrujących treści nieodpowiednie dla małoletnich. Wydaje się to istotne dla ochrony zdrowia $\mathrm{z}$ co najmniej trzech powodów - możliwości uniknięcia kontaktu z materiałami pornograficznymi, zapobieżenia występowaniu ryzykownych zachowań seksualnych i zapobieżenia występowaniu negatywnych skutków psychospołecznych u małoletnich.

Wskazuje się, że $42 \%$ adolescentów mogło mieć styczność z materiałami pornograficznymi, co jednak istotne, aż w 66\% przypadków kontakt ten był niezamierzony [19]. Podaje się, że część dzieci styka się z pornografią w sposób nieintencjonalny, np. przez niechciane e-maile [20]. Wprowadzenie zatem narzędzia, które pozwoliłoby filtrować wskazane treści o charakterze pornograficznym, mogłoby pozwolić na uniknięcie nieintencjonalnego kontaktu $\mathrm{z}$ materiałami pornograficznymi. W konsekwencji możliwe jest ograniczenie wcześniejszej, potencjalnie szkodliwej seksualizacji [21], co może być szczególnie istotne w świetle danych, że wczesny kontakt z pornografią koreluje z uzależnieniem od niej w latach późniejszych [22].

Jak wskazywano wcześniej, sugeruje się, że treści pornograficzne wpływają na kształtowanie się nieprawidłowego $^{11}$ obrazu relacji seksualnych [23]. Ukazano, że oglądanie materiałów pornograficznych może skutkować wcześniejszym $^{12}$ podejmowaniem zachowań seksualnych [24], co może się wiązać z częstszym doświadczaniem problemów

\footnotetext{
${ }^{10} \mathrm{Z}$ uwagi na to, że w celu uniknięcia potencjalnie negatywnych skutków zetknięcia się z materiałami pornograficznymi lepiej jest wywoływać nadmierne „fałszywe alarmy” i filtrować dane zdjęcia, niż popełniać błędy przeoczenia.

${ }^{11}$ Nieprawidłowego, ponieważ może być przedstawiany taki rodzaj aktywności seksualnej, do którego w rzeczywistości może dochodzić w przyszłości nieporównywalnie rzadziej, i wpływającego na niezgodne z rzeczywistością przekonania odnośnie do seksualności.

${ }^{12}$ Rozumiany jako kontakt seksualny, który był oceniany przez co najmniej jedną stronę (zwykle dziewczęta) jako niechciany i zbyt wczesny.
} 
associated with risky behaviours, including irregular contraception [25]. Also, frequent contact with pornographic materials in adolescence is associated with engaging in casual sexual behaviour and a higher incidence of risky sexual practices, for example the use of psychoactive substances during sexual activity [26]. Moreover, viewing pornographic content is associated with the manifestation of sexual aggression ${ }^{13}$ [27]. The introduction of effective pornographic material filtering measures would, then, provide a prevention system for early contact with pornographic materials and therefore the risky behaviors mentioned here.

It seems that there is cultural permission for the objectification and commercial exploitation of both the female and male bodies [28]. One of the obvious consequences of this is that adolescents who view pornographic content often suffer from an inferiority complex when it comes to their physical appearance [29]. Traditionally, attention has been given to the objectification of women, but pornography is also associated with negative consequences for men [30]. Boys who declared that they viewed pornographic materials were more likely to be dissatisfied with their bodies and expressed concerns about their sexual performance [31]. As a consequence, they may experience difficulties in the future in establishing romantic relationships, due to the depiction of women in an objectified manner [32]. Among girls, contact with pornographic materials may cause lower self-esteem, due to the feeling of not being able to live up to the appearance of women depicted in pornographic images [cf. 33]. This means they may be more likely to seek the idealized appearance projected by the media. These possible negative psycho-social effects may also be prevented by the introduction of effective filters.

\section{CONCLUSIONS}

The aim of the research was to create a model that could distinguish between pornographic (including fetishistic) and non-pornographic images of women. The following categories of pornographic materials were included: "AB/DL", "BDSM", "acrotomophilia", "fetishism - feet", "fetishism - gravitophilia", "fetishism - high heels", "fetishism - knee socks", "fetishism - latex", "fetishism tattoos". Using the sAI 0.3 output model, the ResNet152 architecture and the fast.ai library, a model was created that allows for binary classification between pornographic and non-pornographic images with a $96 \%$ accuracy of classification. The model created in this way can be used to filter out content that might be unsuitable for minors from a psychological perspective. The use of similar

\footnotetext{
${ }^{13}$ However, it should be noted that the phenomenon of aggression is more complex. The use of pornographic materials may be one of the behaviors of aggressive people, and not always the cause of aggression.
}

seksualnych w wieku dojrzałym, w porównaniu z osobami, które rozpoczęły aktywność seksualną w późniejszym czasie [6]. Wczesny wiek rozpoczęcia współżycia seksualnego jest związany również z podejmowaniem zachowań ryzykownych, związanych m.in. z nieregularnym stosowaniem antykoncepcji [25]. Częsty kontakt $z$ materiałami pornograficznymi u adolescentów wiąże się też z nawiązywaniem przypadkowych kontaktów seksualnych i większym przyzwoleniem na ryzykowne zachowania seksualne, przykładowo ze stosowaniem substancji psychoaktywnych podczas aktywności seksualnej [26]. Ponadto zwraca się uwagę, że oglądanie treści pornograficznych wiąże się z przejawianiem agresji seksualnej $[27]^{13}$. Wprowadzenie skutecznych filtrów materiałów pornograficznych mogłoby zatem pozwolić na uniknięcie przedwczesnego kontaktu z materiałami pornograficznymi, a przez to zapobiec występowaniu zachowań ryzykownych.

Wydaje się, że istnieje kulturowe przyzwolenie na uprzedmiotowienie i wykorzystanie w sposób komercyjny ciała zarówno kobiety, jak i mężczyzny [28]. Wymienia się, że jedną z konsekwencji powyższej obserwacji jest to, że oglądanie treści pornograficznych jest źródłem kompleksów dotyczących wyglądu u adolescentów [29]. Tradycyjnie zwraca się uwagę na uprzedmiotowianie kobiet, niemniej dla mężczyzn wiąże się to również z negatywnymi konsekwencjami [30]. Chłopcy, którzy deklarowali oglądanie materiałów pornograficznych, wykazywali również częściej niezadowolenie ze swojego ciała, mieli ponadto obawy co do swojej sprawności seksualnej [31]. W konsekwencji oglądanie przez chłopców treści pornograficznych może powodować $\mathrm{w}$ przyszłości trudność $\mathrm{w}$ tworzeniu relacji romantycznych, ze względu na ukazanie obrazów, w których kobiety są przedstawione w sposób przedmiotowy [32]. U dziewczynek styczność z materiałami pornograficznymi może powodować obniżenie samooceny, ze względu na poczucie niedorównania wyglądowi kobiet przedstawionych na zdjęciach pornograficznych [por. 33]. Mogą przez to dążyć do pożądanego przez media wyglądu. $\mathrm{Z}$ tego powodu wprowadzenie skutecznych filtrów materiałów pornograficznych mogłoby zapobiec ewentualnym negatywnym skutkom psychospołecznym.

\section{WNIOSKI}

Celem badań było stworzenie modelu pozwalającego na różnicowanie między zdjęciami o charakterze pornograficznym (również fetyszystycznym) i zdjęciami kobiet o charakterze niepornograficznym. Do grupy materiałów pornograficznych włączono następujące kategorie materiałów pornograficznych: „AB/DL”, „BDSM”, ,akrotomofilia”, „fetyszyzm - stopy”, „fetyszyzm - grawiditofilia”, „fety-

\footnotetext{
${ }^{13}$ Należy jednak pamiętać, że zjawisko agresji jest bardziej złożone. Korzystanie z materiałów pornograficznych może być jednym z zachowań osób cechujących się agresją, a nie zawsze jej przyczyną.
} 
models in the future could support the work of court sexologists. The limitation of the model is that it does not sufficiently account for male sexual activity.

\section{NOTE}

The sAI 0.4 model and its documentation is registered in the OSF database and is available under the following DOI number: 10.17605/OSF.IO/9N7HS. szyzm - szpilki”, „fetyszyzm - podkolanówki”, „fetyszyzm - lateks”, „fetyszyzm - tatuaże”. Korzystając z modelu wyjściowego sAI 0.3, architektury ResNet152 oraz biblioteki fast.ai, stworzono model pozwalający na klasyfikację binarną między zdjęciami pornograficznymi a niepornograficznymi z 96\% dokładnością klasyfikacji. Stworzony w ten sposób model może zostać wykorzystany w celu filtrowania treści, które mogłyby być nieodpowiednie dla małoletnich z perspektywy psychologicznej. Zastosowanie podobnych modeli w przyszłości mogłoby pozwolić na wsparcie pracy seksuologów sądowych. Ograniczeniem modelu jest brak wystarczającego uwzględnienia aktywności seksualnej podejmowanej przez mężczyzn.

\section{ADNOTACJA}

Model sAI 0.4 wraz z dokumentacją został zarejestrowany w bazie OSF i jest dostępny pod następującym numerem DOI: 10.17605/OSF.IO/9N7HS.

\section{Conflict of interest/Konflikt interesu}

Absent./Nie występuje.

Financial support/Finansowanie

Absent./Nie występuje.

\section{References/Piśmiennicłwo}

1. Attwood F, Smith C, Barker M. 'I'm just curious and still exploring myself': Young people and pornography. New Media \& Society 2018; 20: 3738-3759.

2. Barker M. Psychology and pornography: Some reflections. Porn Studies 2014; 1: 120-126.

3. Izdebski Z. Seksualność Polaków na początku XXI wieku. Studium badawcze. Kraków: Wydawnictwo Uniwersytetu Jagiellońskiego; 2012.

4. Włodarczyk J. Zagrożenia związanie z korzystaniem z Internetu przez młodzież. Wyniki badania EU NET ADB. Dziecko Krzywdzone. Teoria, badania, praktyka 2013; 12: 49-68.

5. Madkour AS, Farhat T, Halpern CT, Godeau E, Gabhainn SN. Early adolescent sexual initiation and physical/ psychological symptoms: a comparative analysis of five nations. J Youth Adolesc 2010; 39: 1211-1225.

6. Kosunen E, Kaltiala-Heino R, Rimpelä M, Laippala P. Risk-taking sexual behaviour and self-reported depression in middle adolescence - a school-based survey. Child Care Health Dev 2003; 29: 337-344.

7. Lake BM, Ullman TD, Tenenbaum JB, Gershman SJ. Building machines that learn and think like people. Behav Brain Sci 2017; 40: e253.

8. Oronowicz-Jaśkowiak W. The application of neural networks in the work of forensic experts in child abuse cases. Adv Psychiatry Neurol 2019; 28: 273-282.

9. Moustafa M. Applying deep learning to classify pornographic images and videos. arXiv preprint, 2015. Available at: https://arxiv.org/abs/1511.08899.

10. Perez M, Avila S, Moreira D, Moraes D, Testoni V, Valle E, Rocha A. Video pornography detection through deep learning techniques and motion information. Neurocomputing 2017; 230: 279-293.

11. Jin X, Wang Y, Tan X. Pornographic image recognition via weighted multiple instance learning. IEEE Trans Cybern 2019; 49: 4412-4420.

12. Wang Y, Kosiński M. Deep neural networks are more accurate than humans at detecting sexual orientation from facial images. J Pers Soc Psychol 2018; 114: 246-257.

13. Oronowicz-Jaśkowiak W. Pilotażowy model sieci neuronowej do zastosowań związanych z klasyfikacją siedmiu typów materiałów pornograficznych. Przegląd Seksuologiczny 2019; 19: 21-31.

14. Oronowicz-Jaśkowiak W, Róg K, Siwiak A. Klasyfikacja dziewięciu typów materiałów pornograficznych za pomocą modelu sAI 0.3 [In press]. 
Binary classification of pornographic and non-pornographic materials using the sAl 0.4 model and the modified sexACT database

Klasyfikacja binarna materiałów pornograficznych i niepornograficznych za pomoca modelu sAl 0.4 z wykorzystaniem zmodyfikowanej bazy sexACT

15. Jeremy H. Fast.ai software library. Available at: www.fast.ai. (Accessed: 10.07.2019).

16. Fisher WA, Kohut T. Reading pornography: methodological considerations in evaluating pornography research. J Sex Med 2020; 17: 195-209.

17. He K, Zhang X, Ren S, Sun J. Deep residual learning for image recognition. In: Proceedings of the IEEE conference on computer vision and pattern recognition 2016; 770-778.

18. Smith LN. Cyclical learning rates for training neural networks. IEEE Winter Conference on Applications of Computer Vision 2017; 464-472.

19. Makaruk K, Włodarczyk J, Michalski P. Kontakt dzieci i młodzieży z pornografią. Raport z badań 2017. Fundacja Dajemy Dzieciom Siłę.

20. Trojanowska P. Seksualizacja dzieci i młodzieży - przyczyny, przejawy, konsekwencje i propozycje przeciwdziałania. Dziecko krzywdzone. Teoria, badania, praktyka 2014; 13: 55-78.

21. Harper C, Hodgins DC. Examining correlates of problematic internet pornography use among university students. J Behav Addict 2016; 5: 179-191.

22. Jędrzejk M, Sarzała D. Jak (czy w ogóle można) zapobiegać prostytucji? In: Jędrzejko M (ed.). Prostytucja jako problem społeczny, moralny i zdrowotny. Pułtusk: Akademia Humanistyczna im. Aleksandra Gieysztora; 2006.

23. Brown JD, L'Engle KL. X-Rated: sexual attitudes and behaviors associated with U.S. early adolescents' exposure to sexually explicit media. Communication Research 2009; 36: 129-151.

24. Imacka J, Bulsa M. Ryzykowne zachowania seksualne młodzieży jako czynnik zwiększający ryzyko zakażenia chorobami przenoszonymi drogą płciową. Hygeia Public Health 2012; 47: 3.

25. Braun-Courville DK, Rojas M. Exposure to sexually explicit web sites and adolescent sexual attitudes and behaviours. J Adolesc Health 2009; 45: 156-162.

26. Ybarra ML, Mitchell KJ. Exposure to Internet pornography among children and adolescents: anational survey. Cyberpsychol Behav 2005; 8: 473-486.

27. Birbeck D, Drummond M. Understanding boys' bodies and masculinity in early childhood. International Journal of Men's Health 2006; 5: 238-250.

28. Izdebski Z, Wąż K. Zdrowie seksualne i reprodukcyjne młodzieży. Zdrowie Publiczne i Zarządzanie 2014; 12: 45-55.

29. Vandenbosch L, Eggermont S. Sexualization of adolescent boys: media exposure and boys' internalization of appearance ideals, self-objectification, and body surveillance. Men and Masculinities 2013; 16: 283-306.

30. Owens E, Behun R, Manning J, Reid R. The impact of internet pornography on adolescents: a review of the research. Sexual Addictions and Compulsivity 2012; 19: 99-122.

31. Chodecka A. Masturbacja - czynnik rozwoju czy ryzykowne zachowanie w psychoseksualnym funkcjonowaniu chłopców. Przegląd Seksuologiczny 2009; 17: 7-13.

32. Krasuski T, Żelazo M. The beliefs of women regarding the use of pornography by men. Seksuologia Polska 2017; 15: 57-62.

33. Durham MG. Efekt Lolity. Wizerunek nastolatek we współczesnych mediach i jak sobie z nim radzić. Warszawa: Prószyński Media; 2010. 